\title{
The taxonomic value of rostral nodes of extinct sharks, with comments on previous records of the genus Lamna (Lamniformes, Lamnidae) from the Pliocene of Lee Creek Mine, North Carolina (USA)
}

\author{
FREDERIK H. MOLLEN ${ }^{1}$ AND JOHN W.M. JAGT ${ }^{2}$ \\ ${ }^{1}$ Elasmobranch Research, Meistraat 16, B-2590 Berlaar, Belgium. \\ E-mail:frederik.mollen@telenet.be \\ ${ }^{2}$ Natuurhistorisch Museum Maastricht, de Bosquetplein 6-7, NL-6211 KJ Maastricht, the Netherlands. \\ E-mail:john.jagt@maastricht.nl
}

\begin{abstract}
:
Mollen, F.H. and Jagt, J.W.M. 2012. The taxonomic value of rostral nodes of extinct sharks, with comments on previous records of the genus Lamna (Lamniformes, Lamnidae) from the Pliocene of Lee Creek Mine, North Carolina (USA). Acta Geologica Polonica, 62 (1), 117-127. Warszawa.
\end{abstract}

Shark rostral nodes from the Yorktown Formation (Zanclean, early Pliocene) of Lee Creek Mine, North Carolina (USA), previously assigned to the genus Lamna Cuvier, 1816, have been reinterpreted using a preliminary identification key for extant Lamniformes based on rostral morphology. In addition, the fossil rostral nodes have been compared in detail with Recent material of both the porbeagle, Lamna nasus (Bonnaterre, 1788) and the salmon shark, Lamna ditropis Hubbs \& Follet, 1947. Despite the fact that the rostra compared relatively well with those of Recent Lamna, the Lee Creek Mine specimens proved to differ significantly in having near-parallel lateral rostral cartilages that join the rostral node individually, instead of abutting ones. Based on this observation, we here propose to strike the genus Lamna from the Lee Creek Mine faunal list, so long as no other diagnostic material is forthcoming. These partially preserved rostra are likely to have belonged to extinct taxa within the families Lamnidae or Otodontidae, both of which have been documented from the Yorktown Formation on the basis of isolated teeth of at least three species, Cosmopolitodus hastalis (Agassiz, 1838), Megaselachus megalodon (Agassiz, 1835) and Parotodus benedenii (Le Hon, 1871).

Key words: Lamnidae; Otodontidae; Lamna nasus; Lamna ditropis; Carcharodon; Cosmopolitodus; Megaselachus; Parotodus; Rostrum; Rostral node; CT scans.

\section{INTRODUCTION}

Neogene strata along the Atlantic Coast of North America have been yielding one of the most diverse and abundant elasmobranch faunas worldwide (see e.g. Gibbes 1848-1849; Leidy 1877; Eastman 1904; Fowler 1911; Leriche 1942; Case 1980; Müller 1999). Shark and batoid faunas of Lee Creek Mine near Aurora, North
Carolina (USA) have been described in detail by Purdy et al. (2001), who identified around 60 species from the Pungo River and Yorktown formations, of early Miocene (Burdigalian) and early Pliocene (Zanclean) age, respectively. With the exception of three species, all taxa have been identified on the basis of isolated oral and/or rostral teeth. Several of these taxa are also represented by other material, including vertebrae, rostral nodes, pre- 
and postorbital processes, dermal denticles and caudal or clasper spines (for details, see Table 1). Purdy et al. (2001) considered these remains to be diagnostic or noted examples where they were found in association with teeth, for instance for Hemipristis serra Agassiz, 1835. However, three additional taxa were identified on the basis of non-dental material only, namely Lamna sp. (rostral nodes; 6 specimens), Dasyatis centroura (Mitchill, 1815) (dermal denticles; about 350 specimens) and Manta sp. (caudal spines; 30 specimens).

In addition to dermal denticles and spines, which are occasionally used to document the occurrence of specific elasmobranch taxa and even to erect new ones (see Zangerl 1981; Cappetta 1987, 2006), Purdy et al. (2001) were the first to describe shark rostral nodes from the fossil record and use them in compiling faunal lists. The use of rostral morphology as an important character in shark taxonomy is, however, not new. Regan (1906) first introduced this morphological character in the classification of extant sharks and, following publication of papers by White $(1936,1937)$, rostral cartilages became widely accepted in elasmobranch systematics. In spite of some controversy in the past (see Maisey 1984), rostral cartilages can no longer be ignored in cladistic analyses and phylogenetic studies of modern elasmobranchs (Compagno 1990; de Carvalho 1996; Shirai 1996). In addition to their usefulness in distinguishing higher-rank groups, rostral cartilages of all extant lamniforms known to date are unique and diagnostic (see Compagno 1990), allowing species to be differentiated. This also holds true for both species of Lamna; in fact, discrimination of L. nasus and L. ditropis based on rostral morphology, is relatively straightforward (Mollen 2010).

Attempts by Purdy et al. (2001, pp. 73, 123) to characterise the Lee Creek nodes more specifically failed due to the lack of comparative material. In addition, illustrations and detailed descriptions of rostra prove to be few and far between in the literature, even for lamniforms (Mollen 2010). Based on personal comments by Leonard J.V. Compagno, Purdy et al. (2001) favoured assignment of their rostral nodes to L. ditropis, but, ultimately, recorded them in open nomenclature, Lamna sp. Here, we have subjected the Lee Creek Mine rostral nodes to a preliminary identification key of Lamniformes based on rostral morphology and introduced by Mollen (2010). In addition, these specimens have been compared in detail to rostral nodes of the only modern representatives of the genus Lamna, L. nasus and L. ditropis. Both species attain total lengths in excess of $300 \mathrm{~cm}$, occur in coastal and oceanic waters, but their geographic distribution differs. Lamna nasus inhabits the North Atlantic and a circumglobal belt of temperate water in the southern hemisphere, whereas $L$. ditropis is restricted to the North Pacific (Compagno 2001).

Unlike $L$. ditropis, which is not yet known from the fossil record, teeth of L. nasus occur in the Breda Formation (late Miocene, Tortonian-Messinian) of the southern Netherlands (de Jong 1999; Peters 2009) and in the Kattendijk Formation (early Pliocene, Zanclean) of northern Belgium (Herman et al. 1974; Herman 1979; Ottema and in 't Hout 1987; Nolf 1988). Miocene strata in the southern Netherlands have also recently yielded rostral nodes of L. nasus (Mollen 2010).

\begin{tabular}{|c|c|c|c|c|c|c|c|}
\hline & Oral teeth & Vertebrae & Rostral nodes & $\begin{array}{l}\text { Pre-/post- } \\
\text { orbital } \\
\text { processes }\end{array}$ & $\begin{array}{l}\text { Dermal } \\
\text { denticles }\end{array}$ & Caudal spines & Clasper spines \\
\hline $\begin{array}{l}\text { SQUATINIFORMES } \\
\text { Squatinidae } \\
\text { Squatina sp. }\end{array}$ & $\mathrm{x}$ & $x$ & & & & & \\
\hline $\begin{array}{l}\text { LAMNIFORMES } \\
\text { Cetorhinidae } \\
\text { Cetorhinus sp. } \\
\text { Lamnidae } \\
\text { Lamna sp. }\end{array}$ & $x$ & & $x$ & & & & $x$ \\
\hline $\begin{array}{l}\text { CARCHARHINIFORMES } \\
\text { Hemigaleidae } \\
\text { Hemipristis serra } \\
\text { Carcharhinidae } \\
\text { Carcharhinus spp. } \\
\text { Galeocerdo cf. cuvier }\end{array}$ & $\begin{array}{l}x \\
x \\
x\end{array}$ & $\begin{array}{l}(X) \\
X \\
X\end{array}$ & $\mathrm{x}$ & $x$ & & & \\
\hline $\begin{array}{l}\text { RAJIFORMES } \\
\text { Dasyatidae } \\
\text { Dasyatis centroura } \\
\text { Mobulidae } \\
\text { Manta sp. } \\
\text { Mobula sp. }\end{array}$ & $\mathrm{x}$ & & & & $x$ & $\begin{array}{l}\mathrm{X} \\
\mathrm{x} \\
\mathrm{x}\end{array}$ & \\
\hline
\end{tabular}

Table 1. List of all Lee Creek Mine elasmobranch taxa represented by other than dental material (based on Purdy et al. 2001). Legend: $\mathrm{X}=$ present and diagnostic, 


\section{MATERIAL AND METHODS}

Specimens are housed in the following collections: ERB, Elasmobranch Research Belgium; FMNH, Field Museum of Natural History, Chicago, Illinois, USA; IRScNB, Institut royal des Sciences naturelles de Belgique, Brussels, Belgium; KZNSB, KwaZulu-Natal Sharks Board; NBNM, Nationaal Beiaard- en Natuurmuseum, Asten, the Netherlands; NMFS-AFSC, National Marine Fisheries Service-Alaska Fisheries Science Center; USNM, United States National Museum, Washington DC.

Fossil material includes six rostral nodes (USNM 474994-474999; see Text-fig. 1A-C for USNM 474998), ranging in lateral width between 19 and $36 \mathrm{~mm}$, all from spoil heaps (ex situ) of the Yorktown Formation of Lee Creek Mine near Aurora, North Carolina, and all assigned to Lamna sp. by Purdy et al. (2001, p. 123, fig. $32 b-c)$.

Comparative Recent material comprises specimens of all modern lamnid species (Text-figs 2-3), collected either from fish markets or obtained through scientific institutions worldwide. These were scanned using a Philips Brilliance 40-slice CT scanner, following the method and parameter settings as described by Mollen (2010). Viewing and volume rendering was made possible through Philips Extended Brilliance Workspace V 3.5.0.2254, eFilm Lite ${ }^{\mathrm{TM}}$ and $i Q-V I E W$ software, version 2.6.0 (2009) (courtesy of F. Hilte and J. Bauwens, ZNA hospitals, Antwerp, Belgium). In addition, dried chondrocrania of Carcharodon carcharias (Linnaeus, 1758), Isurus oxyrinchus Rafinesque, 1810 and L. nasus were examined (IRScNB and KZNSB collections), as well as CT scans taken from a juvenile specimen of $C$. carcharias (alcohol preserved) at the Children's Memorial Hospital, Chicago (courtesy of K. Shimada). Available data for all specimens examined are listed below, as are references to illustrations of lamnid chondrocrania in the literature.

\section{SYSTEMATIC DESCRIPTIONS}

Genus Carcharodon Smith in Müller \& Henle, 1838 Carcharodon carcharias (Linnaeus, 1758)

FRESH MATERIAL: One female (ERB0932 = KZNSB-UMT07015), $2120 \mathrm{~mm}$ total length, 26 November 2007, protective gill nets off Umtentweni, South Africa, southwest Indian Ocean.

ADDITIONAL MATERIAL: Two dried chondrocrania. IRScNB 1385 $\gamma$, 1 May 1900, sex and length unknown,
Mediterranean; one female (KZNSB unlabelled), 3740 $\mathrm{mm}$ total length (based on skeleton), date unknown, protective gill nets off KwaZulu-Natal, South Africa, southwest Indian Ocean, and one set of transverse views through rostrum based on CT scans (unpublished data, courtesy of K. Shimada) of a female (FMNH 38335), c. $2714 \mathrm{~mm}$ total length (based on crown height of first anterior teeth, following the method described by Shimada 2003), off southern Florida, USA, Atlantic Ocean (see Text-fig. 3A).

ADDITIONAL ILLUSTRATIONS: Haswell (1884, pl. 1, figs 1-2), Parker (1887, pl. 4, figs 1, 3; pl. 5, unnumbered fig. (upper part of plate only); non pl. 8, figs 24 25, misidentified by the author, see Francis 1996 and Mollet et al. 2002), Compagno (1990, figs 3G, 5J, 6J, 7J), Gottfried et al. (1996, fig. 5B), Wroe et al. (2008, fig. 1A-B) and Shimada et al. (2009, fig. 2D).

Genus Isurus Rafinesque, 1810

Isurus oxyrinchus Rafinesque, 1810

FRESH MATERIAL: Two specimens. ERB0933, female, $1940 \mathrm{~mm}$ total length, 20 February 2009, Algeciras fish market, Spain, $29^{\circ} 10^{\prime} \mathrm{N}, 15^{\circ} 20^{\prime} \mathrm{W}$, northeast Atlantic Ocean (see Text-fig. 3B); and ERB0934, sex unknown (said to be male, but unverified), $2300( \pm 100) \mathrm{mm}$ total length, 26 February 2009, Concarneau fish market, France, northeast Atlantic Ocean.

ADDITIONAL MATERIAL: Three dried chondrocrania. IRScNB 1384 $\gamma, 3$ April 1902, juvenile specimen, sex and length unknown, Mediterranean; IRScNB 2190, 1894, juvenile specimen, sex and length unknown, Nice, France, Mediterranean; and IRScNB 2190ß, 31 March 1892, juvenile specimen, sex and length unknown, Nice, France, Mediterranean.

ADDITIONAL ILLUSTRATIONS: Matsubara (1955, fig. 15D-F), Glikman (1967, figs 8-9, 38; 1980, fig. 2; pls 1-4), Compagno (1990, figs 5K, 6K, 7K; 2001, fig. 12A-C), Muñoz-Chápuli and De Andrés (1995, fig. 1C), Wilga (2005, fig. 3D) and Shimada et al. (2009, fig. 2C).

\section{Isurus paucus Guitart Manday, 1966}

FRESH MATERIAL: One female (ERB0935), 2540 mm total length, 23 July $2008,40^{\circ} 24^{\prime} \mathrm{N}, 67^{\circ} 23^{\prime} \mathrm{W}$, northwest Atlantic Ocean (see Text-fig. 3C). 
ADDITIONAL ILLUSTRATIONS: Compagno (1990, figs $5 \mathrm{~L}, 6 \mathrm{~L}, 7 \mathrm{~L})$.

Genus Lamna Cuvier, 1816

Lamna ditropis Hubbs \& Follet, 1947

FRESH MATERIAL: Two specimens. ERB0937, female, $900 \mathrm{~mm}$ total length, August 2009, beached south of Monterey Bay near San Luis Obispo and Cambria, northeast Pacific Ocean; and ERB0854 (= NMFSAFSC-09SS004; see Text-figs 2A, 3D); female, 2340 $\mathrm{mm}$ total length, 2 October 2009, northeast side of Kodiak Island, northeast Pacific Ocean.

ADDITIONAL ILLUSTRATIONS: Matsubara (1955, fig. 15A-C), Compagno (1977, fig. 7Q; 1988, fig. 7.1.A; 1990, figs 5M, 6N, 7M (non fig. 6M, mislabelled), Glikman (1980, fig. 1.1-2) and Purdy et al. (2001, fig. 32A).

\section{Lamna nasus (Bonnaterre, 1788)}

FRESH MATERIAL: Three specimens. ERB0928, male, $1620 \mathrm{~mm}$ total length, 21 September 2007, La Rochelle fish market, France, northeast Atlantic Ocean; ERB0929, male, $1740 \mathrm{~mm}$ total length, same date and provenance; and ERB0930; male, $1660 \mathrm{~mm}$ total length, same date and provenance (see Text-figs 2B, 3E).

ADDITIONAL MATERIAL: Five dried chondrocrania. IRScNB 476, juvenile specimen, sex, length and provenance unknown; IRScNB 1352 $\beta$, subadult specimen, male, length unknown, Belgium, North Sea; IRScNB 1353, adult specimen, sex, length and provenance unknown; IRScNB 2189, 1892, juvenile speci- men, sex and length unknown, Nice, France, Mediterranean; and IRScNB 2189ß, May 1902, juvenile specimen, sex, length and provenance unknown.

ADDITIONAL ILLUSTRATIONS: Parker (1887, pl. 4, figs 2, 4; pl. 5, unnumbered fig. (lower part of plate only); Garman (1913, pl. 62, figs 1-3); Block and Carey (1985, fig. 4A-B), Chevrier (1986, p. 6, unnumbered figs), Compagno (1990, figs 5N, 6M, 7N; non Fig. 6N, mislabelled), Goto (1996, fig. 5D), Wilga (2005, fig. 3C) and Mollen (2010, fig. 4A-B; pls 1-3).

\section{MORPHOLOGICAL DESCRIPTION OF LEE CREEK MINE MATERIAL}

Systematics for fossil and Recent taxa follow Cappetta (2006) and Compagno (2001, 2005), respectively. For publication dates of taxa described by Agassiz (1833-1844), we adopt Woodward and Sherborn (1890), while descriptive terminology is adapted mainly from Compagno $(1988,1990,2001)$ and Mollen (2010).

The six partial rostra assigned to Lamna sp. by Purdy et al. (2001) are robust, well calcified and of tripodal form. Although none of the specimens are preserved in their entirety, no signs of rostral fenestrae or rostral appendices are detected. The remains of all three rostral cartilages are more or less stout, positioned parallel and expanding individually towards the rostral node base. The rostral cartilages do not abut; instead they all join the rostral node individually. The rostral node bases are more or less circular in cross section. All rostral cartilages have a hollow central core. Along the anterior edge, the rostral nodes are rounded in both dorsal and lateral views. Rostral node appendices, rostral node fenestrae, and transverse ridges are absent.

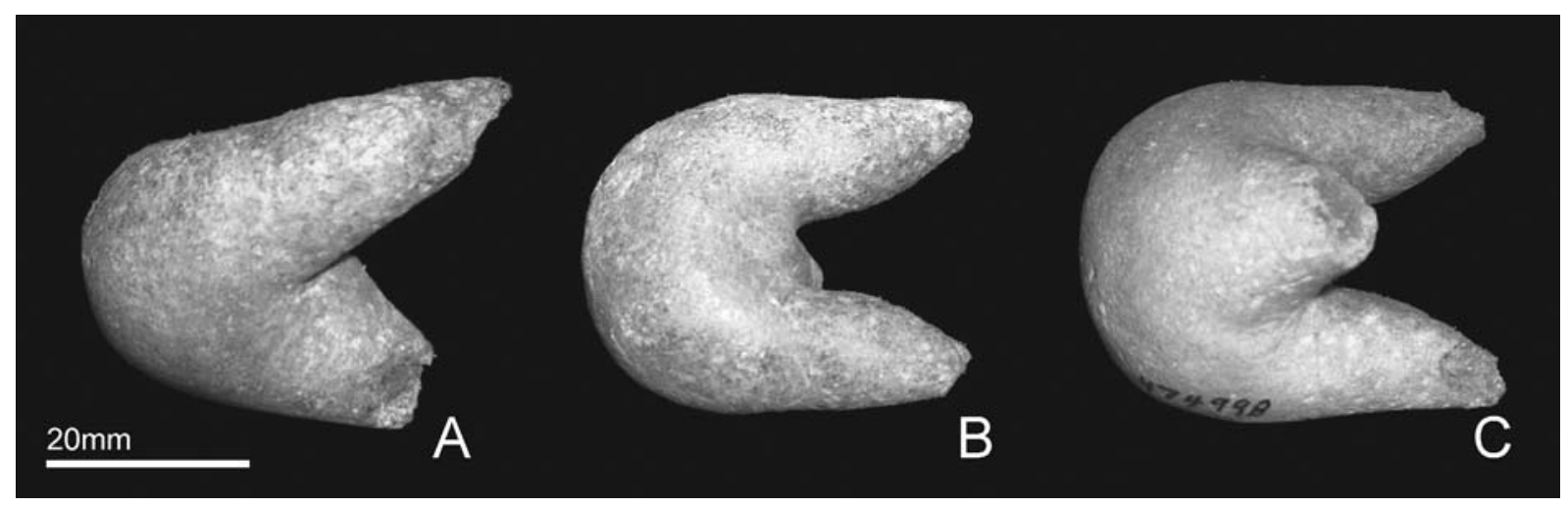

Text-fig. 1. Lamniformes incertae sedis, partial tripodal rostrum (USNM 474998), Yorktown Formation (early Pliocene, Zanclean), Lee Creek Mine, North Carolina (USA), in lateral (A), dorsal (B) and ventral views (C). Photos courtesy of Robert W. Purdy 


\section{COMPARISONS AND DISCUSSION}

\section{Order level}

All rostral nodes recorded to date from Lee Creek Mine are of tripodal form. In spite of some controversy in the past (Maisey 1984), such tripodal rostra occur exclusively in the Lamniformes and Carcharhiniformes (Mollen 2010). After Compagno (1988) had rejected Glikman's (1967) statement that the Lamniformes differed from the Carcharhiniformes in that their lateral rostral cartilages are attached to the preorbital wall and supraorbital crest, no character was left to distinguish rostra of both orders. However, based on illustrations of a wide array of carcharhinoid and lamnoid taxa by Compagno (1988, 1990, respectively), very large and robust rostra occur exclusively in the Lamniformes (Mollen 2010). The same feature is also present in the six Lee Creek Mine specimens examined in the present study.

\section{Family level}

The Lee Creek Mine specimens are very robust, not elongated, of tripodal form with lateral cartilages that are

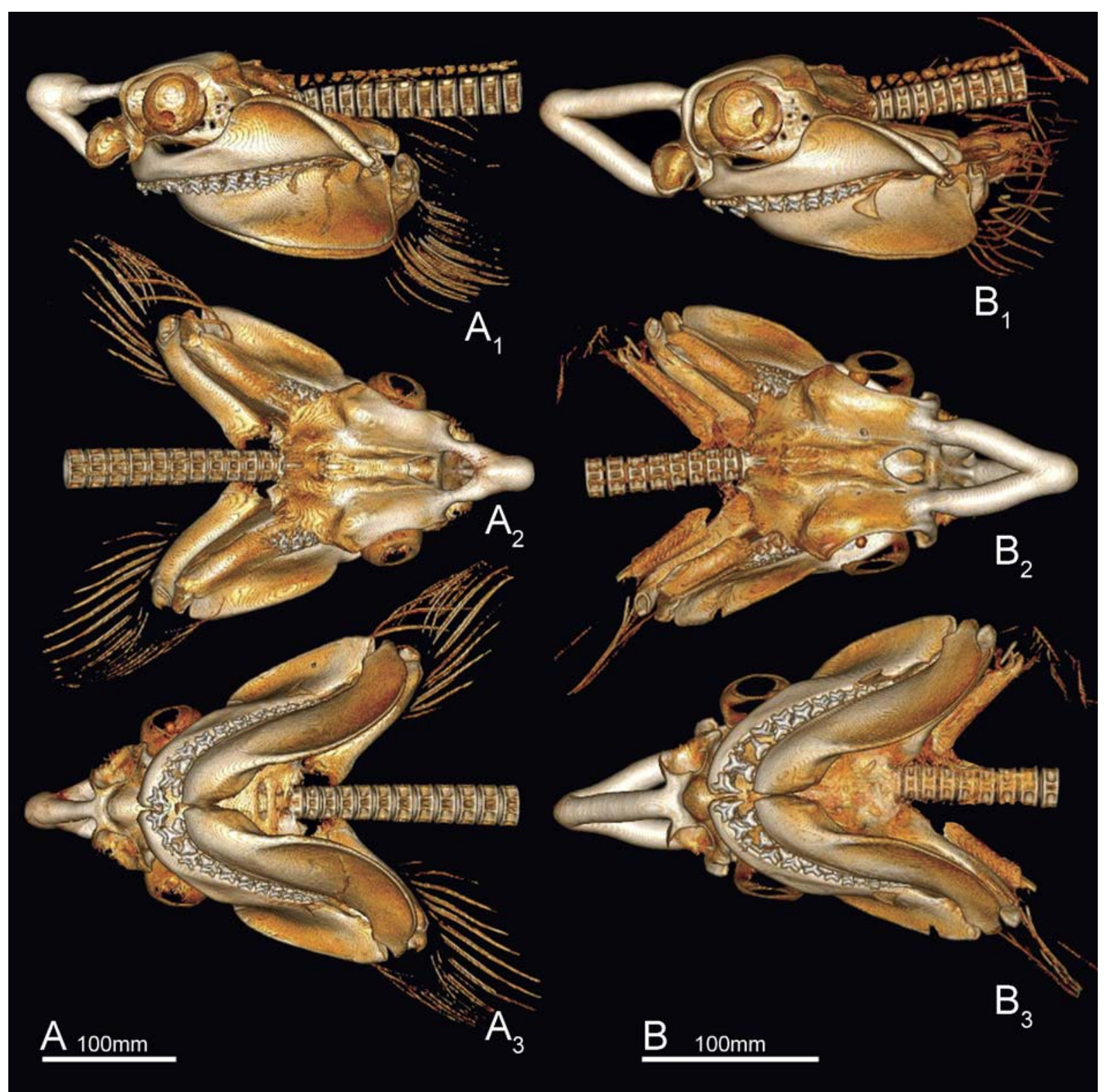

Text-fig. 2. Comparative anatomy of rostra of modern Lamna; 3D volume rendered images based on CT scans of the entire heads. A. Lamna ditropis Hubbs \& Follett, 1947, female, $2340 \mathrm{~mm}$ total length, northeast Pacific Ocean (ERB0854), B. Lamna nasus (Bonnaterre, 1788), male, $1740 \mathrm{~mm}$ total length, northeast Atlantic 
positioned nearly parallel. On the basis of the rostral identification key to Recent post-natal lamniform sharks, as presented by Mollen (2010), these characters preclude assignment of these nodes to the Alopiidae, in which lateral rostral cartilages are very thin and delicate (see e.g. Molin 1860), the Mitsukurinidae which have elongated rostra and rostral nodes (see e.g. Compagno 1990), the Cetorhinidae which show complex tripodal rostra with a false rostral node and an extremely broad and flat medial rostral cartilage (see e.g. Pavesi 1874, 1878), or the Megachasmidae in which lateral cartilages meet under an obtuse angle (> 100 degrees) (see e.g. Taylor et al. 1983). In addition, there is no evidence of lateral vertical fenestrae, which also rules out placement in either the Odontaspididae or Pseudocarchariidae (see e.g. Compagno 1990). Within the Lamniformes, this leaves only the Lamnidae or Otodontidae. The latter is the sole extinct lamniform family known from Miocene and Pliocene deposits globally (see Cappetta 1987, 2006). However, it cannot be ruled out completely that they in fact represent another extinct family, unknown to date.

\section{Genus and species level}

Recent lamnids are represented by three genera: Carcharodon, Isurus and Lamna. According to Purdy et al. (2001), the Lee Creek Mine rostral nodes compared favourably with those of extant L. nasus and L. ditropis, with a slight preference for the latter species.
Rostra of Lamna differ from all other modern lamnids most significantly by having the bases of their rostral cartilages attached exclusively to the preorbital processes (see Compagno 1990; Mollet et al. 2002; Mollen 2010; Text-fig. 2A $\mathrm{A}_{1}-\mathrm{B}_{1}$ ). The bases of the Lee Creek Mine rostra are, however, not preserved; therefore, this feature could not be scored. The rostral cartilages of the Lee Creek Mine specimens are relatively stout and well calcified, and the anterior edge of the rostral node is rounded in both dorsal and lateral views. In this respect, we concur with Purdy et al. (2001) that the Lee Creek Mine material matches rostra of the Recent genus Lamna. Moreover, these rostral nodes are indeed closer to $L$. ditropis than to L. nasus because all three rostral cartilages expand significantly towards the rostral node base (see Text-fig. 2A). In the latter species they are almost of equal size along the entire rostral cartilages (see Text-fig. 2B).

However, despite these resemblances, the Lee Creek Mine material differs significantly from Recent Lamna in having rostral cartilages that are, although well calcified, less stout and exhibit near-parallel lateral rostral cartilages that do not abut, but join the rostral node individually (see Text-figs 2, 3D-E). As a result, a knob as present in L. ditropis (see Text-fig. $3 \mathrm{D}_{1}$ ), or a ventral and dorsal groove as seen in L. nasus (see Text-fig. $3 \mathrm{E}_{1}$ ), are absent in the Lee Creek Mine material. Although ontogenetic changes do occur in L. nasus (see Mollen 2010), variations in rostral morphology reflecting the phenomenon are different from those observed.

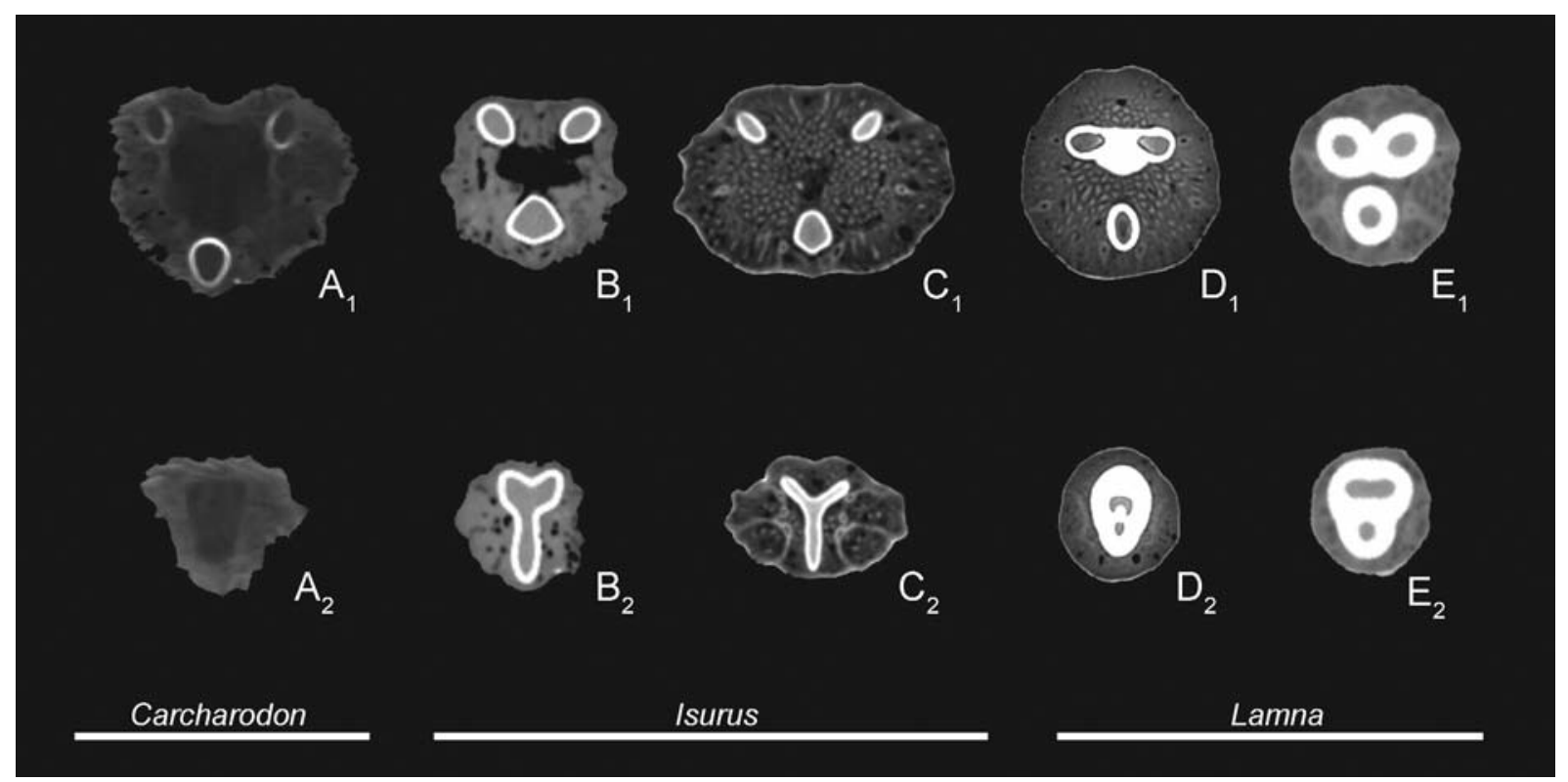

Text-fig. 3. Visual identification key to modern lamnid genera based on transverse slices through the rostrum (not to scale): in between mid-portion of rostrum and rostral node base (1) and rostral node base (2). A. Carcharodon carcharias (FMNH 38335): uncalcified rostral node. B-C. Isurus oxyrinchus (ERB0933) and I. paucus (ERB0935), respectively, with calcified, Y-shaped rostral node base. D-E. Lamna ditropis (ERB0854) and L. nasus (ERB0929), respectively, with hypercalcified 
At the generic level, the Lee Creek material also deviates markedly from other extant genera of the Lamnidae, namely Isurus and Carcharodon. These are both represented in the Lee Creek Mine faunas, by at least two species, I. oxyrinchus and C. carcharias (see Table 2). Unlike Isurus (Text-fig. 3B-C), Lee Creek Mine rostral nodes are more robust, not elongated, have a rounded rostral apex ( $v s$. pointed) and do not have a Y-shaped rostral node base. Additionally, a kink as present in the lateral rostral cartilages of Isurus (see e.g. Compagno 1990, 2001) is absent in the material examined here. The Lee Creek Mine material differs from Carcharodon in being much more calcified and in having lateral cartilages that are circular in cross section ( $v s$. transversely flattened).

For these reasons, we reject assignment of these nodes to the genera Lamna, Isurus and Carcharodon. In view of the fact that there are no other options left within modern Lamnidae, we assume these rostral nodes to have belonged to one or more extinct, closely related taxa.

\section{Extinct Lee Creek Mine taxa}

Based on isolated oral teeth, Purdy et al. (2001) recorded five extinct species from the Lee Creek Mine that have traditionally been assigned to the Lamnidae or Otodontidae (see Table 2). Except for 'Carcharodon' subauriculatus Agassiz, 1839, whose occurrence is restricted to the Pungo River Formation, all these forms have been documented from the Yorktown Formation which also yielded the rostral nodes. Although we cannot be certain that the dental record of large lamnids, otodontids or other closely related extinct taxa, in the Lee Creek faunas is complete (e.g. note the absence of $\mathrm{An}$ otodus retroflexus (Agassiz, 1838) from faunal lists by Purdy et al. 2001), it is unlikely that these rostral nodes would have belonged to yet (an)other species of which there is no dental record yet. Therefore, it is highly probable that these nodes could be assigned to one of these extinct lamnid or otodontid taxa from the Yorktown For- mation at Lee Creek. For now, however, we cannot offer any additional arguments for a more specific attribution.

Purdy et al. (2001) assigned both Oxyrhina hastalis Agassiz, 1838 and O. xiphodon Agassiz, 1838 to the Recent genus Isurus. Even though the Lee Creek rostral nodes deviate from those of Isurus (in not having a Yshaped base), we cannot rule out the possibility that they did belong to either ' $O$. ' hastalis or 'O. 'xiphodon, because the proper taxonomic position of these two taxa (based solely on dental characters) is still an unresolved point. In fact, several authors (e.g. Leriche 1926; Cappetta 1987,2006$)$ considered $O$. xiphodon a junior synonym of $O$. hastalis, while Glikman (1964) assigned the latter to his newly erected genus Cosmopolitodus, an extinct lamnid which some authors consider to be the predecessor of the great white shark and thus more closely related to the genus Carcharodon (see e.g. Casier 1960; Ehret et al. 2009).

The generic assignment of Carcharodon megalodon Agassiz, 1835 is controversial as well. Purdy et al. (2001) adopted its original designation, which would allow us to eliminate the possibility that the rostral nodes belonged to that species, but several other authors (e.g. Casier 1960; Cappetta 1987; Ehret et al. 2009) have previously argued that Carcharodon carcharias evolved independently of C. megalodon, thus requiring the erection of a new genus for the extinct form (see Carcharocles Jordan and Hannibal in Jordan, 1923; Procarcharodon Casier, 1960; Megaselachus Glikman, 1964). In addition, Glikman (1964) even assigned Megaselachus to a new family of extinct lamnids, the Otodontidae. Because of this taxonomic controversy, it is not possible either, based on the identification key to Recent Lamniformes, to rule out the possibility that the Lee Creek Mine rostral nodes did in fact belong to ' $C$ '. megalodon.

The same applies for Oxyrhina benedenii Le Hon, 1871, a large lamnoid that was assigned by Van de Geyn (1937) to the genus Isurus. If indeed a species of Isurus, its rostral node base would have been Y-shaped. Based

\begin{tabular}{|c|c|c|c|}
\hline \multicolumn{2}{|c|}{ Purdy et al. (2001) } & & \multicolumn{2}{c|}{ Cappetta (2006) } \\
\hline Family & Species & Status & Species \\
Lamnidae & Isurus oxyrinchus & Recent & Family \\
Lamnidae & Isurus hastalis & Extinct & Cosmopolitodus hastalis \\
Lamnidae & Isurus xiphodon & Cosmopolitodus hastalis \\
Lamnidae & Lamna sp. & Lecent & Lamna sp. \\
Lamnidae & Carcharodon carcharias & Recent & Carcharodon carcharias \\
Lamnidae & Carcharodon megalodon & Extinct & Megaselachus megalodon \\
Lamnidae & Carcharodon subauriculatus & Extinct & Megaselachus megalodon \\
Lamnidae & Parotodus benedenii & Extinct & Parotodus benedenii \\
\hline
\end{tabular}

Table 2. Taxonomic correlation of species occurring at Lee Creek Mine (Aurora, North Carolina) and assigned to the Lamnidae or Otodontidae; note the absence of Anotodus retroflexus (Agassiz, 1838) 
on this, we can exclude assignment of the Lee Creek Mine rostral nodes (which have circular rostral node bases) to this species. Its taxonomic position is, however, also controversial, which means that this species currently cannot be ruled out. Cappetta (1980) erected the genus Parotodus for this species, a decision subscribed to by some subsequent workers such as Siverson (1999) and Purdy et al. (2001), except that Cappetta initially assigned the new genus to the Otodontidae, whilst Purdy et al. and Siverson placed it amongst the Lamnidae and Cardabiodontidae, respectively. The latter is yet another family of fossil lamnoids which was erected to accommodate an extinct genus, Cardiabiodon Siverson, 1999, from the Cenomanian (Late Cretaceous) of Australia.

\section{CONCLUSIONS}

Based on comparative morphology, rostral nodes from the Yorktown Formation of Lee Creek Mine, previously assigned to the genus Lamna, appear to differ markedly from Recent L. nasus and L. ditropis, which is why we propose to eliminate the genus Lamna from the Lee Creek Mine faunal list, so long as no other diagnostic material is forthcoming. Attempts to assign these fragmentary rostra favour placement in an extinct taxon (or taxa) within the Lamnidae or Otodontidae, which are represented by teeth of at least three species in the same strata (C. hastalis, M. megalodon and $P$. benedenii). However, specific identification of isolated lamnid-like rostral nodes, such as the Lee Creek Mine material, will probably remain impossible until found in association with teeth. Such discoveries will not only document proper rostral node attribution, but might also shed light on the familial and generic assignment of these problematic taxa and thus on interrelationships of Neogene lamniforms which are still hotly debated. We therefore encourage more detailed studies of fossil chondrocranial material available and, in particular, of rostra.

\section{Acknowledgements}

We thank H. van der Steen (Oss) and R. van der Vliet (Uden) for bringing fossil shark rostral nodes to our attention and supplying material; R.W. Purdy (NMNH, Washington DC) for photographs of Lee Creek specimens; S.H. Kim and K. Shimada (both DePaul University, Chicago) for sharing data; G. Lenglet (IRScNB, Brussels), J.B. Domínguez and D. Macías (both IEO, Fuengirola), D. Casper, S. Van Sommeran (both PSRF, Capitola), K. Goldman (ADFG, Homer), S.P. Iglésias (MNHN, Concarneau), L. Natanson (NMFS, Narra- gansett), B. Rivasseau (Foro Maree, La Rochelle), S. Winter (KZNSB, Umhlanga Rocks), M.A. Rogers, K. Swagel, M. Westneat and P. Willink (all FMNH, Chicago) for donation and loan of or access to comparative Recent material; F. Hilte and J. Bauwens (both ZNA hospitals, Antwerp) and B. Reilly, C.K. Rigsby, K. Gray, B. Karl, and J. Hickey (all CMH, Chicago) for CT scanning and imaging; M.R. de Carvalho (São Paulo University) for helpful discussions; D.J. Ehret (Monmouth University, New Jersey) and an anonymous reviewer for constructive comments.

\section{REFERENCES}

Agassiz, L. 1833-1844. Recherches sur les poissons fossiles, 3, pp. viii + 1-390+1-32. Petitpierre; Neuchâtel.

Block, B.A. and Carey, F.G. 1985. Warm brain and eye temperatures in sharks. Journal of Comparative Physiology, B156, 229-236.

Bonnaterre, J.P. 1788. Tableau encyclopédique et méthodique des trois règnes de la nature. Ichthyologie, pp. lvi + 1215. Panckoucke; Paris.

Cappetta, H. 1980. Modification du statut générique de quelques espèces de sélaciens crétacés et tertiaires. Palaeovertebrata, 10 (1), 29-42.

Cappetta, H. 1987. Chondrichthyes II. Mesozoic and Cenozoic Elasmobranchii. In: H.-P. Schultze (Ed.), Handbook of Paleoichthyology 3B, pp. viii $+1-193$. G. Fischer; Stuttgart/New York.

Cappetta, H. 2006. Elasmobranchii post-triadici (index specierum et generum). In: W. Riegraf (Ed.), Fossilium Catalogus, I: Animalia 142, pp. v $+1-472$. Backhuys Publishers; Leiden.

Carvalho, M.R. de. 1996. Higher-level elasmobranch phylogeny, basal squaleans, and paraphyly. In: M.L.J. Stiassny, L.R. Parenti and G.D. Johnson (Eds), Interrelationships of fishes, pp. 35-62. Academic Press; San Diego.

Case, G.R. 1980. A selachian fauna from the Trent Formation, Lower Miocene (Aquitanian) of eastern North Carolina. Palaeontographica A171 (1-3), 75-103.

Casier, E. 1960. Note sur la collection des poisons paléocènes et éocènes de l'Enclave de Cabinda (Congo) recueillis par J. Bequaert au cours de sa mission en 1913. Annales du Musée royal du Congo belge A3(1)2, 1-48.

Chevrier, F. 1986. Requins actuels et requins des faluns. Famille des Isuridés, pp. 1-48. Groupe des géologues amateurs du F.L.E.R.C.; Tours.

Compagno, L.J.V. 1977. Phyletic relationships of living sharks and rays. In: R.G. Northcutt (Ed.), Recent advances in the biology of sharks. American Zoologist, 17, 303-322.

Compagno, L.J.V. 1988. Sharks of the order Carcharhini- 
formes, pp. xxii $+1-486$. Princeton University Press; Princeton.

Compagno, L.J.V. 1990. Relationships of the megamouth shark, Megachasma pelagios (Lamniformes: Megachasmidae), with comments on its feeding habits. In: H.L. Pratt, S.H. Gruber and T. Taniuchi (Eds), Elasmobranchs as living resources: advances in the biology, ecology, systematics, and the status of the fisheries. NOAA Technical report NMFS, 90, 357-379.

Compagno, L.J.V. 2001. Sharks of the world. An annotated and illustrated catalogue of shark species known to date. Volume 2. Bullhead, mackerel and carpet sharks (Heterodontiformes, Lamniformes and Orectolobiformes). FAO Species Catalogue for Fishery Purposes, 1 (2), pp. viii $+1-269$.

Compagno, L.J.V. 2005. Checklist of living Chondrichthyes. In: W.C. Hamlett (Ed.), Reproductive biology and phylogeny of Chondrichthyes. Sharks, batoids and chimaeras. In: B.G.M. Jamieson (Ed.), Reproductive biology and Phylogeny 3, pp. 503-548. Science Publishers; Enfield.

Cuvier, G. 1816. Le règne animal distribué d'après son organisation, pour servir de base à l'histoire naturelle des animaux et d'introduction a [sic] l'anatomie comparée. Tome II. Les reptiles, les poissons, les mollusques et les annelids, pp. xviii $+1-532$. Déterville; Paris.

Eastman, C.R. 1904. Pisces. In: Maryland Geological Survey, Miocene, pp. 71-93. Johns Hopkins Press; Baltimore.

Ehret, D.J., Hubbell, G. and MacFadden, B.J. 2009. Exceptional preservation of the white shark Carcharodon (Lamniformes, Lamnidae) from the early Pliocene of Peru. Journal of Vertebrate Paleontology, 29, 1-13.

Fowler, H.W. 1911. A description of the fossil fish remains of the Cretaceous, Eocene and Miocene formations of New Jersey. Geological Survey of New Jersey, Bulletin, 4, 1-192.

Francis, M.P. 1996. Observations on a pregnant white shark with a review of reproductive biology. In: A.P. Klimley and D.G. Ainley (Eds), Great white sharks, the biology of Carcharodon carcharias, pp. 157-172. Academic Press; San Diego.

Garman, S. 1913. The Plagiostomia (sharks, skates, and rays). Memoirs of the Museum of Comparative Zoölogy at Harvard College, 36, pp. xiii + 1-515.

Gibbes, R.W. 1848-1849. Monograph of the fossil Squalidae of the United States. Journal of Natural Sciences of Philadelphia, new series, 1 (1-2), 139-147, 191-206.

Glikman, L.S. 1964. Paleogene sharks and their stratigraphic significance, pp. 1-229. Nauka; Moscow/Leningrad. [In Russian]

Glikman, L.S. 1967. Subclass Elasmobranchii (sharks). In: D.V. Obruchev (Ed.), Fundamentals of paleontology, 11,
Agnatha, Pisces, pp. 292-352. Israel Program for Scientific Translations; Jerusalem.

Glikman, L.S. 1980. Evolution of Cretaceous and Cenozoic lamnoid sharks, pp. 1-248. Nauka; Moscow. [In Russian]

Goto, T. 1996. Phylogenetic relationships of galeomorph sharks - elucidation of higher-level systematics. Kaiyo Monthly, 28, 338-345. [In Japanese]

Gottfried, M.D., Compagno, L.J.V. and Bowman, S.C. 1996. Size and skeletal anatomy of the giant "megatooth" shark Carcharodon megalodon. In: A.P. Klimley and D.G. Ainley (Eds), Great white sharks, the biology of Carcharodon carcharias, pp. 55-66. Academic Press; San Diego.

Guitart Manday, D. 1966. Nuevo nombre para una especie de tiburón del género Isurus (Elasmobranchii: Isuridae) de aguas cubanas. Poeyana, A15, 1-9.

Haswell, W.A. 1884. Studies on the elasmobranch skeleton. Proceedings of the Linnean Society of New South Wales, 9, 71-119.

Herman, J., Crochard, M. and Girardot, M. 1974. Quelques restes de sélaciens récoltés dans les sables du Kattendijk à Kallo. I. Selachii - Euselachii. Bulletin de la Société belge de Géologie, 83 (1), 15-31.

Herman, J. 1979. Réflexions sur la systématique des Galeoidei et sur les affinités du genre Cetorhinus à l'occasion de la découverte d'éléments de la denture d'un exemplaire fossile dans les sables du Kattendijk à Kallo (Pliocène inférieur, Belgique). Annales de la Société géologique de Belgique, 102, 357-377.

Hubbs, C.L. and Follett, W.I. 1947. Lamna ditropis, new species, the salmon shark of the North Pacific. Copeia, 1947 (3), 194.

Jong, A. de. 1999. Haaien- en roggentanden uit Liessel (N.B.). Een 'paleozoölogisch' onderzoek, pp. 1-69. Fontys Hogescholen; Tilburg (unpublished).

Jordan, D.S. 1923. A classification of fishes including families and genera as far as known. Stanford University Publications, University Series, Biological Sciences, 3 (2), pp. 77-243 + x.

Le Hon, H. 1871. Préliminaires d'un mémoire sur les poissons tertiaires de Belgique, pp. 1-15. Muquardt (Merzbach, successeur); Bruxelles.

Leidy, J. 1877. Description of vertebrate remains, chiefly from the phosphate beds of South Carolina. Journal of the Academy of Natural Sciences of Philadelphia, new series, 8 (3), 209-261.

Leriche, M. 1926. Les poisons néogènes de la Belgique. Mémoires du Musée royal d'Histoire naturelle de Belgique, 32, 367-472.

Leriche, M. 1942. Contribution à l'étude des faunes ichthyologiques marines des terrains tertiaires de la Plaine Cotière Atlantique et du centre des États-Unis. Le synchronisme des formations tertiaires des deux cotés de 
l'Atlantique. Mémoires de la Société géologique de France, 45, 1-112.

Linnaeus, C. 1758. Systema naturae per regna tria naturae, secundum classes, ordines, genera, species, cum characteribus, differentiis, synonymis, locis. Tomus I. Editio decima, reformata, pp. iv $+1-824$. Laurentii Salvii; Holmiae.

Maisey, J.G. 1984. Higher elasmobranch phylogeny and biostratigraphy. Zoological Journal of the Linnean Society, 82, 33-54.

Matsubara, K. 1955. Fish morphology and hierarchy, Part I, pp. 1-789. Ishizaki-Shoten; Tokyo.

Mitchill, S.L. 1815. The fishes of New York, described and arranged. Transactions of the Literary and Philosophical Society of New York, 1, 355-492.

Molin, R. 1860. Sullo scheletro degli Squali. Memorie dell'Istituto Reale Veneto di Scienze, Lettere ed Arti, 8 (1859), 391-481.

Mollen, F.H. 2010. A partial rostrum of the porbeagle shark Lamna nasus (Lamniformes, Lamnidae) from the Miocene of the North Sea Basin and the taxonomic importance of rostral morphology in extinct sharks. Geologica Belgica, 13 (1-2), 61-76.

Mollet, H.F., Testi, A.D., Compagno, L.J.V. and Francis, M.P. 2002. Re-identification of a lamnid shark embryo. Fishery Bulletin, 100, 865-875.

Müller, A. 1999. Ichthyofaunen aus dem atlantischen Tertiär der USA. Systematik, Paläoökologie, Biostratigraphie und Paläobiogeographie. Leipziger Geowissenschaften, 9-10, pp. 1-360.

Müller, J. and Henle, F.G.J. 1838. On the generic characters of cartilaginous fishes, with description of new genera. The Magazine of Natural History, new series 2, 33-37, 88-91.

Muñoz-Chápuli, R. and De Andrés, A.V. 1995. Anatomy and histology of the cephalic arterial coilings in hammerhead sharks (genus Sphyrna). Acta Zoologica, 76(4), 301-305.

Nolf, D. 1988. Fossielen van België. Haaie- en roggentanden uit het Tertiair van België, pp. 1-180. Koninklijk Belgisch Instituut voor Natuurwetenschappen; Brussel.

Ottema, J. and in 't Hout, W. 1987. Fossielen uit het $4^{\mathrm{e}}$ havendok bij Kallo, België, pp. 1-113. Geologisch Museum Artis Amsterdam; Amsterdam.

Parker, T.J. 1887. Notes on Carcharodon rondeletii. Proceedings of the Scientific Meetings of the Zoological Society of London, 1887, 27-41.

Pavesi, P. 1874. Contribuzione alla storia natural del genere Selache. Annali del Museo civico di Storia naturale di Genova, 6, 5-72.

Pavesi, P. 1878. Seconda contribuzione alla morfologia e sistematica dei Selachi. Annali del Museo civico di Storia naturale di Genova, 12, 348-418.
Peters, N. 2009. Brabant tussen walvissen en mastodonten. Fossielen uit Liessel, pp. 1-110. Nationaal Beiaard- en Natuurmuseum; Asten/Oertijdmuseum De Groene Poort; Boxtel.

Purdy, R.W., Schneider, V.P., Applegate, S.P., McLellan, J.H., Meyer, R.L. and Slaughter, B.H. 2001. The Neogene sharks, rays, and bony fishes from Lee Creek Mine, Aurora, North Carolina. In: C.E. Ray and D.J. Bohaska (Eds), Geology and paleontology of the Lee Creek Mine, North Carolina, III. Smithsonian Contributions to Paleobiology, 90, 71-202.

Rafinesque, C.S. 1810. Caratteri di alcuni nuovi generi e nuove specie di animali e piante della Sicilia con varie osservazioni sopra i medesimi, pp. 1-105. Sanfilippo; Palermo.

Regan, C.T. 1906. A classification of selachian fishes. Proceedings of the Zoological Society of London, 1906, $722-758$.

Shimada, K. 2003. The relationship between the tooth size and total body length in the white shark, Carcharodon carcharias (Lamniformes: Lamnidae). Journal of Fossil Research, 35 (2), 28-33.

Shimada, K., Rigsby, C.K. and Kim, S.H. 2009. Labial cartilages in the smalltooth sandtiger shark, Odontaspis ferox (Lamniformes: Odontaspididae) and their significance to the phylogeny of lamniform sharks. The Anatomical Record, 292, 813-817.

Shirai, S. 1996. Phylogenetic interrelationships of neoselachians (Chondrichthyes: Euselachii). In: M.L.J. Stiassny, L.R. Parenti and G.D. Johnson (Eds), Interrelationships of fishes, pp. 9-34. Academic Press; San Diego.

Siverson, M. 1999. A new large lamniform shark from the uppermost Gearle Siltstone (Cenomanian, Late Cretaceous) of Western Australia. Transactions of the Royal Society of Edinburgh, Earth Sciences, 90, 49-66.

Taylor, L.R., Compagno, L.J.V. and Struhsaker, P.J. 1983. Megamouth - a new species, genus, and family of lamnoid shark (Megachasma pelagios, family Megachasmidae) from the Hawaiian Islands. Proceedings of the California Academy of Sciences, (4)43(8), 87-110.

Van de Geyn, W.A.E. 1937. Das Tertiär der Niederlande mit besonderer Berücksichtigung der Selachierfauna. Leidsche Geologische Mededelingen, 9, 177-361.

White, E.G. 1936. A classification and phylogeny of the elasmobranch fishes. American Museum Novitates, 837, $1-16$.

White, E.G. 1937. Interrelationships of elasmobranchs with a key to the order Galea. Bulletin of the American Museum of Natural History, 74, 25-138.

Wilga, C.D. 2005. Morphology and evolution of the jaw suspension in lamniform sharks. Journal of Morphology, 265, 102-119. 
SHARKS FROM THE PLIOCENE OF NORTH CAROLINA

Woodward, A.S. and Sherborn, C.D. 1890. A catalogue of British fossil Vertebrata, pp. xxxv + 1-396. Dulau \& Co; London.

Wroe, S., Huber, D.R., Lowry, M., McHenry, C., Moreno, K., Clausen, P., Ferrara, T.L., Cunningham, E., Dean, M.N. and Summers, A.P. 2008. Three-dimensional computer analysis of white shark jaw mechanics: how hard can a great white bite? Journal of Zoology, 276, 336-342.

Zangerl, R. 1981. Chondrichthyes, I. Paleozoic Elasmobranchii. In: H.-P. Schultze (Ed.), Handbook of Paleoichthyology 3A, pp. vi $+1-116$. G. Fischer; Stuttgart/New York.

Manuscript submitted: 12 ${ }^{\text {th }}$ July 2011

Revised version accepted: $15^{\text {th }}$ January 2012 